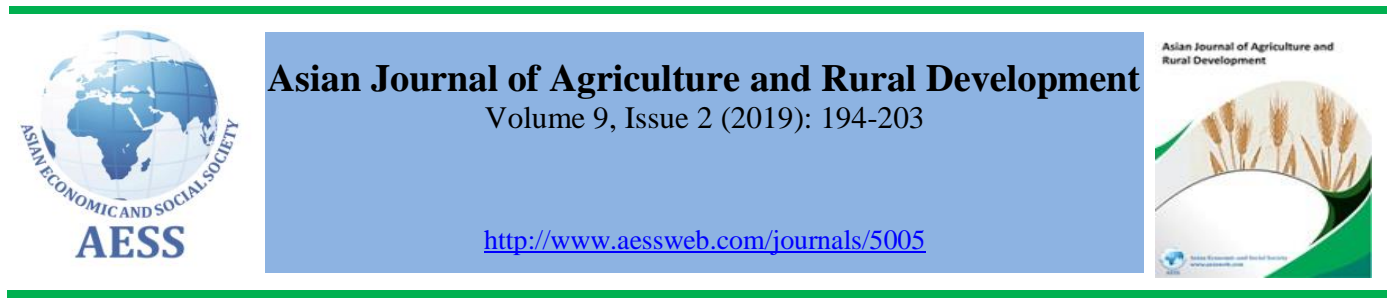

\title{
ASSESSMENT OF THE PERFORMANCE OF FARMERS' COOPERATIVE SOCIETIES: A CASE OF KADUNA STATE NIGERIA
}

Chuks C. Ezeh ， College of Agriculture, Ahmadu Bello University, Zaria Nigeria

M. Abubakar

$\bowtie$ chukezeh14@gmail.com (Corresponding author)

\section{ARTICLE HISTORY: \\ Received: 25-Apr-2019 \\ Accepted: 02-Sep-2019 \\ Online Available: $19-$ Sep- 2019}

Keywords:

Assessment,

Performance,

Farmers,

Cooperative societies

\begin{abstract}
The study was carried out in Soba Local Government Area (LGA) of Kaduna state to appraise the performance of four (4) farmers' cooperative societies using a structured questionnaire administered to 116 randomly selected cooperators. The obtained data were analyzed using descriptive and nonparametric statistics. The results revealed that several factors had motivated members to join societies. The average loan approval rate of $93.3 \%$ was recorded for the 3 -year period of 2015,2016 , and 2017. About 73 cooperators representing $62.9 \%$ assessed the services of the cooperative societies as very satisfactory or satisfactory; only $12.9 \%$ assessed them as not satisfactory. Major constraints that identified include inadequate capital $(19.7 \%)$, limited income generating activities $(16.5 \%)$, and poor attitude of cooperators $(14.5 \%)$.
\end{abstract}

\section{Contribution/ Originality}

This study evaluates the performance of selected cooperative societies in bridging the gap and leveraging on identified constraints, and offers recommendations that will engender better livelihoods among cooperators and concurrently transform Nigerian agriculture.

DOI: 10.18488/journal.1005/2019.9.2/1005.2.194.203

ISSN (P): 2304-1455/ISSN (E):2224-4433

How to cite: Chuks C. Ezeh and M. Abubakar (2019). Assessment of the performance of farmers' cooperative societies: a case of the Kaduna state Nigeria. Asian Journal of Agriculture and Rural Development, 9(2), 194-203.

(C) 2019 Asian Economic and Social Society. All rights reserved. 


\section{INTRODUCTION}

In recent years policy makers, Non-Governmental Organizations (NGOs), and international donor agencies have recognized that improving livelihoods in many low income countries can only be achieved if development efforts are clearly focused on the sector employing most of the poor and the spaces where they live. Undoubtedly that sector is rural farming which in most low income countries constitutes the majority of the poor (Ugwuanyi and Chukwuemeka, 2013).

In Nigeria it is estimated that over 50 percent of the population are poor. The World Bank (2015) report estimated the incidence of poverty to be 53.5 percent with poverty levels more severe in the rural areas. According to Thomas and Canagarajah (2008) Nigeria's economy is characterized by a large agriculturally based sector that encompasses about two thirds of the population living in poverty.

Smallholder farming is typical in rural Nigeria and there is an emerging concern about the viability of small farm agriculture. This, according to Barret et al. (2006), is because these smallholders are faced with daunting livelihood risks resulting from the general state of deprivation they find themselves in; infrastructure is poor, environmental hazards prevail, and income is low resulting from low investment and an uneconomic scale of production. The result is that these smallholders are caught up in a vicious cycle trying to eke out a living and hardly meeting basic living requirements.

The importance of growing the agricultural sector and at the same time improving rural livelihoods cannot be overemphasized. This was amply demonstrated during the economic transformation of Asia. Forty years ago Asia was a continent of widespread poverty. Today most Asian countries are experiencing significant growth and poverty reduction (Otierio, 2007). Nigerian economy has a lot of potential for growth and development, especially the rural farming sector. These potentials must be harnessed to the fullest to generate the expected upscale in rural livelihoods. Perhaps one veritable channel to the realization of this goal is through the encouragement and growth of the cooperative movement (Anyanwu et al., 1997; Otto and Ukpere, 2011).

Cooperatives have been defined severally and in many contexts. The International Cooperative Alliance (ICA, 2001) defined cooperatives as people-centred enterprises jointly owned and democratically controlled by members for members to realize their common socioeconomic needs and aspirations. Ezeh (2003) posited that cooperatives are established by likeminded people to pursue mutually beneficial economic interests generally aimed at enhancing livelihood standards.

The merits of cooperation essentially derive from the characteristic focus on collective action. The facets of collective action may differ from place to place, form one cooperative enterprise to another. These differences manifest in the different types of cooperatives operating in Nigeria; some operate along specific endeavours while others are multipurpose. In all, group or collective action has been recognized as a positive force for rural development. As the name implies, cooperatives perform a number of services to their members such as providing credit and other inputs for production along with storage and marketing facilities for their produce. The credit requirements of members could also be met through grants and loans from government and donor agencies for on-lending to members. Cooperatives encourage and facilitate mobilization of savings among members, thereby filling funding gaps that characterize marginal production.

There is no doubt that pooling their resources together through cooperatives will help unleash unexploited potentials and empower these smallholder farmers. However, success stories of the performance of cooperatives in Nigeria have been few and far between. Studies have shown that attempts to channel funds through cooperatives have not been very successful. A myriad of other 
challenges have been cited in different locations (Ijere, 1998; Otto and Ukpere, 2011; Kanu and Ozurumba, 2014).

Therefore this study aims to assess the performance of selected cooperative societies in the area of study. The objectives of the study are:

- To describe the socioeconomic characteristics of the cooperators in the study area

- To elicit the factors motivating membership of cooperative societies

- To assess the performance of selected cooperative societies

- To identify the constraints mitigating the effectiveness of cooperative societies in the study area.

\section{METHOD OF STUDY}

\subsection{The study area}

The Soba Local Government Area (LGA), one of the 23 LGAs in the state of Kaduna, is located in the north-eastern part of the state along latitudes $10^{0}-15^{0} \mathrm{~N}$ and longitudes $11^{0}-16^{0} \mathrm{E}$. The LGA is bordered by the Zaria LGA in the west and the Kauru LGA in the east. The Soba LGA falls within the Guinea Savanna Zone with annual rainfall range of a variety of arable crops. The major occupation of the inhabitants is farming.

\subsection{Sampling procedure and data collection}

Multistage sampling procedure was adopted in the study, firstly to purposively select the Soba LGA because of the preponderance of active cooperative societies in the local government area. Secondly, two districts out of four were purposively selected because of the number of active societies operating in them. The third stage involved random selection of two (2) cooperative societies per district giving a total of four (4) societies. Finally, thirty (30) members were randomly selected from the membership list provided by the selected societies. The number of randomly selected co-operators per society was limited to 30 firstly because that figure amounted to an average of $50 \%$ of the membership of most of the societies and secondly because the scope of the study was limited by funding and time. A structured questionnaire was used to generate primary data through interviews of the co-operators. 116 (96.7\%) were duly completed and formed the sample size for the study $(\mathrm{n}=116)$.

\section{Table 1: Distribution of co-operators}

\begin{tabular}{lccc}
\hline District / Cooperative & $\begin{array}{c}\text { Questionnaire } \\
\text { administered }\end{array}$ & Questionnaire retrieved & \% retrieved \\
\hline 1. Maigana & & & \\
a. Awai & 30 & 29 & 24.2 \\
b. Tudun Saibu & 30 & 30 & 25 \\
2. Wanka & & & \\
a. Dutse & 30 & 28 & 23.3 \\
b. Tsauni & 30 & 29 & 24.2 \\
Total & 120 & 116 & 96.7 \\
\hline
\end{tabular}

\subsection{Data analysis}

Both descriptive and nonparametric statistics were used to analyze the primary data. Descriptive statistics including frequency and percentages were used to achieve objectives 1,2 , and 4 . Nonparametric statistics including standard deviation and chi-square were used to achieve objective 3:

Standard deviation $\mathrm{S}=$ 


$$
S=\sqrt{\frac{\sum_{i=1}^{N}(x i-\bar{x})^{2}}{N-1}}
$$

where $\left(x_{1}, x_{2} \ldots x_{n}\right)$ are observed values of the sample,

$\mathrm{x}$ is the mean value of the observations, and $N$ is the number of observations in the sample.

Chi-square is explicitly expressed as:

$$
x^{2}=\frac{\left(x_{0}-x_{e}\right)^{2}}{x_{e}}
$$

where $x_{o}$ is the observed frequency and $x_{e}$ is the expected frequency.

\section{RESULTS AND DISCUSSION}

\subsection{Socioeconomic characteristics of co-operators}

Table 2 shows the distribution of major socioeconomic characteristics of the respondents including gender, age, educational attainment, and occupation.

\section{Table 2: Distribution of co-operators according to their socioeconomic characteristics}

\begin{tabular}{lcc}
\hline Characteristic & Frequency $(\mathbf{n}=\mathbf{1 1 6})$ & Percentage \\
\hline Gender & & \\
Male & 83 & 71.5 \\
Female & 33 & 28.5 \\
Age (years) & & \\
$<20$ & 9 & 7.8 \\
$21-30$ & 28 & 24.1 \\
$31-40$ & 32 & 27.6 \\
$41-50$ & 31 & 26.7 \\
$>50$ & 16 & 13.8 \\
Mean & 36.5 & \\
Educational status & & \\
Primary education & 44 & 37.0 \\
Secondary education & 29 & 25.0 \\
Tertiary education & 11 & 9.5 \\
Adult literacy & 18 & 15.5 \\
Non formal education & 14 & 12.1 \\
Occupation & & \\
Farming & 78 & 67.2 \\
Fishing & 9 & 7.8 \\
Traer/business & 21 & 18.1 \\
Civil servant & 8 & 6.9 \\
\hline
\end{tabular}

Source: Field Study, 2018

The results in table 2 show that men constituted $71.5 \%$ of the respondents and women $28.5 \%$. There is no doubt that men dominated in the activities of the cooperative societies covered in the area. This result is similar to the findings of Izekor and Alufohi (2010) in their study of credit cooperatives in the state of Edo, in the South, and Ibitoye (2013) in the state of Kogi, North Central Nigeria.

Only 9 (7.8\%) of the co-operators were below 20 years of age. $24 \%$ fell within 21-30 years. More than half (54.39) of the co-operators fell between 30 and 50 years while 16 co-operators representing $13.8 \%$ were over 50 . The mean age of the respondents in this study was 36.5 years. Evidently the majority (78\%) of the co-operators fell within the productive age of $20-50$ years. 
These results agree with the findings of Babatunde et al. (2007) in their study of farmers in the state of Katsina in Nigeria.

The results in Table 2 also show the educational status of the co-operators. $37.9 \%$ had only primary education, 25\% secondary education, and 9.5\% tertiary education. About $16 \%$ of the cooperators had attended adult literacy programmes operating in the LGA, and 14 respondents, representing $12.1 \%$, had no formal education. These results agree with the findings of Audu et al. (2010) in Dekina LGA of the state of Kogi in Nigeria.

While farming is the predominant occupation of the inhabitants of the Soba LGA, other occupations also featured, mostly with farming as a side occupation. The results show that the majority $(67.2 \%)$ indicated farming as their main occupation. About $18 \%$ of the co-operators were into trading / business, $7.8 \%$ into fishing, and $6.9 \%$ were civil servants. It is noteworthy that most of the civil servants had attained tertiary education.

\subsection{Cooperative membership and motivators}

The study sought to ascertain the duration of membership of the co-operators and what factors motivated their membership in cooperative societies.

Table 3: Distribution of co-operators based on the duration of membership

\begin{tabular}{lcc}
\hline Duration of membership & Frequency & Percentage $(\%)$ \\
\hline$<5$ years & 19 & 16.4 \\
6 - 10 years & 34 & 29.3 \\
11 - 15 years & 50 & 43.1 \\
> 15 years & 13 & 11.2 \\
Mean & 10.4 & \\
Std. Derivation & 4.37 & \\
\hline
\end{tabular}

Source: Field Survey 2018

The results in Table 3 show that 19 co-operators, representing $16.4 \%$ of the sample, have been in cooperative societies for less than 5 years, $29.3 \%$ have been co-operators for $6-10$ years, and $43.1 \%$ have been members for $11-15$ years. Only $11.2 \%$ of the co-operators have been members for over 15 years. The mean duration of membership for the sample is 10.4 years with a standard deviation of 4.37 . Evidently over a half $(54 \%)$ of the co-operators have been members of cooperative societies for over 10 years. This is remarkable since, according to Izekor and Alufohai (2018), the longer the duration of membership, the more experienced members are in the running and operations of cooperative societies. It is also evident that members find cooperation beneficial and hence sustain their membership.

Regarding the major factors that had motivated and endeared members to join cooperative societies, the responses of co-operators are shown in Table 4.

Table 4: Factors that motivated membership in cooperative societies

\begin{tabular}{|c|c|c|c|c|}
\hline \multirow[b]{2}{*}{ Motivating factor } & \multicolumn{3}{|c|}{ Strength of motivation } & \multirow[b]{2}{*}{$\begin{array}{c}\text { Mean } \\
(\mathbf{x})\end{array}$} \\
\hline & $\begin{array}{c}\text { Very } \\
\text { strong (3) }\end{array}$ & $\begin{array}{l}\text { Strong } \\
\text { (2) }\end{array}$ & Mild(1) & \\
\hline 1. To contribute to community development & 42 & 43 & 31 & 2.09 \\
\hline 2. To encourage and enhance savings culture & 68 & 33 & 15 & 2.46 \\
\hline 3. For increased agricultural output/yield & 54 & 41 & 21 & 2.28 \\
\hline 4. To facilitate access to loans and farm inputs & 83 & 24 & 9 & 2.63 \\
\hline 5. To improve members welfare/livelihood & 49 & 42 & 25 & 2.2 \\
\hline
\end{tabular}




\begin{tabular}{llllll}
\hline 6. & To enhance members' self esteem & 36 & 41 & 39 & 1.97 \\
\hline
\end{tabular}

Source: Field study, 2018

Using a benchmark of 2, the Likert type results in Table 4 show that the prospects of access to loans, grants, and farming inputs recorded the highest mean score of 2.63 followed by encouraging and enhancing savings culture (2.46).

The third and fourth ranking motivators were for increased agricultural output/yield (2.28) and to improve members' welfare/livelihood (2.20). Contributing to community development (fifth ranking) barely made the benchmark at 2.09, while enhancing members' self-esteem (1.97) failed to make the benchmark of 2. These results corroborated the findings of Nweze (2003) and Okoli (2018) in their study of cooperatives in Nigerian rural communities.

\subsection{Assessment of cooperative performance}

The study sought to assess the performance of the four cooperatives covered through the cooperators who are beneficiaries and had applied for loans, grants, or other services. The 3-year period of 2015, 2016, and 2017 was covered in this assessment as shown in Table 5.

Table 5: Loan applications and approvals by cooperative societies: 2015 - 2017

\begin{tabular}{lcccc}
\hline Year & $\begin{array}{c}\text { Number of loan } \\
\text { applications }\end{array}$ & $\begin{array}{c}\text { Number of } \\
\text { loans approved }\end{array}$ & $\begin{array}{c}\text { Percentage } \\
\text { approved }\end{array}$ & $\begin{array}{c}\text { Percentage } \\
\text { rejected }\end{array}$ \\
\hline 2015 & 109 & 102 & 93.6 & 6.4 \\
2016 & 112 & 105 & 93.8 & 6.2 \\
2017 & 106 & 98 & 92.5 & 7.5 \\
Mean & 109 & 101.6 & 92.3 & 6.7 \\
Std. Deviation & 3 & 3.52 & 0.49 & 0.49 \\
\hline
\end{tabular}

Source: Field Study, 2018

The results in Table 5 show the number of loan applications and approved loans. The rates were $93.6 \%, 93.8 \%$, and $92.5 \%$ for the years 2015,2016 , and 2017 , giving a mean of $93.3 \%$ approval rate for the three years covered in the study. This was considered reasonably high since, conversely, the percentages of rejected applications were $6.4 \%, 6.2$, and $7.5 \%$ for 2015,2016 , and 2017 with a mean of $6.7 \%$ for the three years. Evidently the co-operators in the four cooperative societies had good access to cooperative loans and benefitted accordingly. These results agree with the findings of Izekor and Alufohai (2010) in the state of Edo where the approval rates were $98.90 \%$ and $99.42 \%$ for 2002 and 2003 .

The value of the loans granted to cooperative members, whether in cash or kind, was ascertained. Loans were in the form of cash advances as well as materials/farm inputs (fertilizers, better seeds, agrochemicals etc.). A breakdown of the values of disbursement made for the three years under review was recorded in Table 6.

Table 6: Distribution according to the value of credit received: $2015-2017$

\begin{tabular}{lccccc}
\hline $\begin{array}{l}\text { Loan value } \\
\text { (N'000) }\end{array}$ & $\begin{array}{c}\mathbf{2 0 1 5} \\
(\mathbf{n = 1 0 2})\end{array}$ & $\begin{array}{c}\mathbf{2 0 1 6} \\
(\mathbf{n = 1 1 2})\end{array}$ & $\begin{array}{c}\mathbf{2 0 1 7} \\
(\mathbf{n = 1 0 6})\end{array}$ & $\mathbf{F}$ & Total \\
\hline $50-100$ & 0 & 2 & 1 & 3 & 0.9 \\
$101-150$ & 3 & 5 & 4 & 12 & 3.8 \\
$151-200$ & 8 & 5 & 7 & 20 & 6.3 \\
$201-250$ & 11 & 9 & 13 & 33 & 10.3 \\
$251-300$ & 11 & 18 & 17 & 56 & 17.5 \\
$301-350$ & 21 & 18 & 17 & 56 & 17.5 \\
\hline
\end{tabular}




\begin{tabular}{lccccc}
\hline $351-400$ & 25 & 28 & 22 & 75 & 23.4 \\
$401-450$ & 13 & 18 & 16 & 47 & 14.7 \\
$451-500$ & 7 & 12 & 11 & 30 & 9.4 \\
$>500$ & 3 & 5 & 4 & 12 & 3.8 \\
\hline
\end{tabular}

Source: Field Study, $2017 *$ USD $1=\$ 362$ (Naira) at 2018 exchange rate

The result in Table 6 shows that out of the 320 approvals for the years $(2015-2017)$ only 12 , representing $3.8 \%$, were for loan values of more than N500,000. Thirty-five approvals, representing $11 \%$, received between $\mathrm{N} 50,000$ and $\mathrm{N} 700,000$. The majority $(61 \%)$ of the approvals fell between N200,000 and 400,000. 89 approvals representing $27 \%$ of the total were recorded in the bracket of $\mathrm{N} 400,000$ and above.

Generally the amount of loans received by the cooperative may be considered low in view of the prevailing inflationary rate resulting in high cost of farm inputs and labour. However, it should be noted that the co-operators are mostly smallholder farmers whose operations and scope are generally on a small scale. Moreover, loans advanced to cooperative members are based on the contributions made by members; they are usually not entitled to more than what they have contributed. At best, in some cases and when funds are available, members may be allowed twice the amounts they have contributed. The results in this study as it relates to the range of advances disbursed are similar to those of Nweze (2003), Otto and Ukpere (2011), and Godwin (2011) in their studies.

From their standpoint the co-operators were asked to assess the performance of their cooperative societies for the 3-year period. They were asked to indicate whether they considered the services rendered by their cooperative societies as very satisfactory, satisfactory, fair, or not satisfactory. Their responses are shown in Table 7.

Table 7: Chi-square analysis of the performance of cooperative prevailing societies: 2015 2017

\begin{tabular}{lccc}
\hline Assessment indies & $\begin{array}{c}\text { Observed frequency } \\
(\mathbf{f o})\end{array}$ & $\begin{array}{c}\text { Expected frequency } \\
(\mathbf{f e})\end{array}$ & $\begin{array}{c}(\mathbf{f o}-\mathbf{f e})^{\mathbf{2}} / \mathbf{f e} \\
\left(\mathbf{X}^{\mathbf{2}}\right)\end{array}$ \\
\hline Very satisfactory & $31(26.7)^{*}$ & 29 & 0.14 \\
Satisfactory & $42(36.2)$ & 29 & 5.83 \\
Fair & $28(24.1)$ & 29 & 0.03 \\
Not satisfactory & $15(12.9)$ & 29 & 6.75 \\
Total & $116(100)$ & - & 12.75 \\
\hline
\end{tabular}

Source: Field study, 2018 * Figures in parenthesis are percentages

The results in Table 7 show that 73 co-operators, representing 62.9\%, assessed the services rendered by their cooperative societies as very satisfactory or satisfactory; $24.1 \%$ as fair, and only 15 co-operators, representing $12.9 \%$, as not satisfactory. The chi square analysis of the assessment by co-operators gave a positive value of $x^{2}=7.4$ in their assessment of the performance of their cooperative.

To further confirm the assessment of the co-operators regarding cooperative performance, chi square was used to test the null hypothesis $\left(\mathrm{H}_{0}\right)$ that cooperation is not beneficial to the wellbeing of the co-operators. They were asked to answer 'yes' if cooperation has been beneficial to their wellbeing or 'no' if it has not been beneficial to their wellbeing and livelihood. 
Table 8: Affirmation of the benefits of cooperative membership

\begin{tabular}{lcccc}
\hline Affirmation & Frequency & df & $\mathbf{x}^{\mathbf{2}}$ & p-value \\
\hline Yes & $91(78.4)$ & 2 & 18.78 & 0.00 \\
No & $25(21.6)$ & 2 & 18.78 & 0.00 \\
Total & $116(100)$ & - & 37.56 & - \\
\hline
\end{tabular}

Source: Field Study, $2018 *$ Figures in parenthesis represent percentages

With the chi-square value of 37.56 (Calc.) the co-operators affirmed that cooperation was beneficial to their wellbeing and livelihood. Therefore the null hypothesis that cooperation is not beneficial to the co-operators' wellbeing is hereby rejected. The alternative hypothesis $\left(\mathrm{H}_{1}\right)$ that cooperation is beneficial to members' wellbeing is accepted.

\subsection{Constraints limiting effectiveness of cooperatives}

The fourth objective of this study sought to identify the major constraints limiting the effectiveness of cooperative societies in the study area. Therefore the co-operators were asked to indicate from a list of problems and challenge those which critically affected the operations of their cooperative societies. Their responses are shown in Table 8.

Table 9: Distribution of co-operators according to constraints that limit the effectiveness of cooperative societies

\begin{tabular}{llcc}
\hline Constraints & Frequency & Percentage \\
\hline i. & Poor management / leadership & 38 & 10.8 \\
ii. $\quad$ Poor attitude of members & 51 & 14.5 \\
iii. $\quad$ Inadequate capital & 69 & 19.7 \\
iv. $\quad$ Misappropriation of society funds & 35 & 10.0 \\
v. Limited income generating activities & 58 & 16.5 \\
vi. Delays in processing of loan applications & 36 & 10.3 \\
vii. & Favoritism and nepotism on the part of officials of society & 16 & 4.5 \\
viii. Low membership strength & 4.8 & 13.7 \\
Total & $351^{*}$ & 100 \\
\hline
\end{tabular}

Source: Field Study, $2018 *$ Multiple response

The result in Table 9 shows that the first three constraints are inadequate capital (19.7\%), limited income generating activities $(16.5 \%)$, and poor attitude of co-operators $(14.5 \%)$ in that order. Low membership strength (13.7\%) was the fourth constraint identified by the co-operators followed by poor management / leadership (19.8\%). The last 3 constraints, in this order, include delays in processing of loan applications (10.3\%), misappropriation of society funds $(10.0 \%)$, and favouritism (nepotism by officials of the society $(4.5 \%)$. Constraints identified in this study are similar to those identified by Ajah (2012), Audu et al. (2010) and Izekor and Alufohai (2010) in their studies of cooperative societies in the states of Edo, Abuja, and Kogi.

\section{CONCLUSION}

It is generally agreed that cooperatives serve as a veritable channel for rural empowerment and development, and that regular and optimal performance of these roles will accelerate the transformation of agriculture and rural economy. The cooperative societies covered in this study in Soba LGA of the state of Kaduna affect the lives of the members positively. This is deduced form the high patronage of services by co-operators and their assessment of the performance of the societies. However, the potential for optimal benefits to members is yet to be truly harnessed. To achieve this goal the following recommendations are proffered: 
1. Cooperative societies should be encouraged to diversify their economic activities and seek more avenues (e.g. grants) to increase funding capacity.

2. Societies should embark on enlightenment and literacy programmes to address poor attitude of cooperators.

3. Since government, donor agencies, and NGOs operate better through cooperatives, societies should link up to such opportunities to expand their scale of operations.

Funding: This study received no specific financial support.
Competing Interests: The authors declared that they have no conflict of interests.
Contributors/Acknowledgement: All authors participated equally in designing and estimation of current
research.
Views and opinions expressed in this study are the views and opinions of the authors, Asian Journal of
Agriculture and Rural Development shall not be responsible or answerable for any loss, damage or liability
etc. caused in relation to/arising out of the use of the content.

\section{References}

Ajah, J. (2012). Effect of farmers' level of education and cooperative membership on access to agricultural extension services in Abuja Nigeria. Trends in Agricultural Economics, 4(5), 104-114. doi.org/10.3923/tae.2012.104.114.

Anyanwu, J. C., Oyefusi, A., Aikhenan, O., \& Dimowo, F. A. (1997). The structure of the Nigerian economy. Joan Educational Publishers, Benin. 594-595.

Audu, S. I., Ibitoye, S. J., \& Umar, H. V. (2010). Comparative economic analysis of cooperative and non - cooperative farmers in the adoption of improved technologies in Dekina LGA of Kogi state Nigeria. International Journal of Agricultural Economics, Management and Development, 1(1), 49-57.

Babatunde, R.O., Omotesho, O. A., \& Sholotan, O. S. (2007). Socio-economic characteristics and food security status of farming households in Kwara state, North-Central Nigeria. Pakistan Journal of Nutrition, 6(1), 49-58. doi.org/10.3923/pjn.2007.49.58.

Barret, C., Bezuneh, A., \& Abdullahi, A. (2006). Income distribution, poverty traps and policy shocks in Cote d'ivoire and Kenya. Food Policy, 26(4), 367-384. doi.org/10.1016/s03069192(01)00017-3.

Ezeh, C. C. (2003). Women empowerment through cooperative formation and coordination. Paper presented at the CTA/DAC Workshop on the promotion of Extension Methodology in Home Economics Skills Acquisition for Nigerian Women in Agriculture. 1-4 ${ }^{\text {th }}$ December, 2003.

Godwin, S. (2011). Poverty reduction through the use of cooperative societies. Review of International Cooperatives, 4, 85-89.

Ibitoye, S. J. (2013). Survey of the performance of agricultural cooperative societies in Kogi State, Nigeria. European Scientific Journal, 8(24), 1-16.

Ijere, M. O. (1998). Agricultural credit and economic development. in Ijere M.O. and Okorie A. (eds). Reading in Financing. Longman, Lagos. Pp. 257.

International Cooperative Association ICA, (2001). Report of the centennial congress of the ICA October. Geneva.

Izekor, A. B., \& Alufohai, G. O. (2010). Assessment of cooperation societies effectiveness in Agricultural Credit delivery in Ikpoba Okha LGA, Edo State. Africa Journal of General Agriculture, 6(3), 139-144.

Kanu, S. I., \& Ozurumba, B. A. (2014). Capital formation and economic growth in Nigeria. Global Journal of Human Social Sciences, 14(4), 41-58.

Nweze, M. J. (2003). Cooperative promotion in rural communities. The project approach. Nigerian Journal of Cooperatives, 2(2), 76-89.

Okoli, E. (2018). Assessment of the contributions of cooperative societies in the development of youths. A case study of selected cooperative societies in Dunukofia LGA, Anambra State, Nigeria MRRA Research Paper No. 84380. Assessed at https://inpra.ub.unimuenchen.de/84380. 
Otierio, A. Z. (2007). Agricultural growth, rural poverty and hunger in Africa. AAAE Conference Proceedings p. 465-468.

Otto, G., \& Ukpere, W. (2011). Credit and thrift cooperative in Nigeria: a potential source of capital formation and employment. African Journal of Business Management, 5(4), 56755680 .

Thomas, S., \& Canagarajah, S. (2008). Poverty in a wealthy economy: The case of Nigeria. IMF Working Paper \# 02/114.

Ugwuanyi, B. I., \& Chukwuemeka, E. C. (2013). Financing rural development in Nigeria. Periscoping Imperatives. Singaporean Journal of Business Economics and Management Studies, 1(8), 1-11.

World Bank (2015). Poverty rates at international poverty lines. World Development Indicators, World Bank Washington DC. 